\title{
Enzyme Inhibitor Protein
}

National Cancer Institute

\section{Source}

National Cancer Institute. Enzyme Inhibitor Protein. NCI Thesaurus. Code C18072.

A class of proteins that are involved in the inhibition of enzymes. 